\title{
Financing Cost and Private Investment in Ghana
}

\author{
Josephine Ofosu-Mensah Ababio", Emmanuel Sarpong Kumankoma, Kofi A. Osei \\ Department of Finance, University of Ghana Business School, University of Ghana, Ghana
}

Copyright $(2018$ by authors, all rights reserved. Authors agree that this article remains permanently open access under the terms of the Creative Commons Attribution License 4.0 International License

\begin{abstract}
This study has investigated empirically the effect of financing cost on private investment in Ghana, over the period 1970 to 2010 . To this end, the variables employed were classified as cost factors (interest rate, exchange rate, inflation rate) and non-cost factors (public investment, output, credit availability, external debt) of private investment. The Johansen co-integration technique was used to estimate the long-run private investment function for Ghana. Also, the Error Correction Model was used to determine the short-run dynamics. The study finds that all the cost factors had negative and statistically significant impact on private investment in Ghana, in the long-run. On the other hand, in the long-run, the non-cost factors impacted positively on private investment in Ghana, but external debt had an adverse effect. It also, finds that all the variables used, co-integrated with private investment in the long-run. This study provides original evidence that high cost of financing is associated with low private sector participation in investment activities in Ghana. Accordingly, the study recommends among others that long term policies should be directed towards cost control and macroeconomic stabilization in order to boost private investment activities or programs in developing nations particularly, Ghana.
\end{abstract}

Keywords Private Investment, Interest Rate, Exchange Rate, Inflation Rate, Johansen Co-integration Technique, Ghana

\section{Introduction}

Investment is fundamental to economic growth both in the developing and the developed nations. Investment is the flow of output in a given period that is used to maintain or increase the capital stock in any economy. It is an essential component of aggregate demands hence fluctuations in investment have considerable effects on economic activities and long-term economic growth. The desire for growth and development of the economies of developing countries brought up the issue of the role of the private sector. Private sector investment is noted as being directly related to economic growth in developing countries [1, 2]. Hence the emphasis is now on private investment as the engine of economic growth and development. Econometric evidence [3-6] indicates that private investment has a stronger and more favorable effect on growth than public investment. In recent years therefore, emphasis has been put on the development of the private sector particularly, in developing countries to help boost economic growth i.e. create more jobs, wealth, reduce unemployment and poverty, through vigorous participation in investment activities.

Private sector investment requires affordable financing. Unfortunately, in Ghana, firms in the private sector are unable to raise much funds needed to finance their investments $[7,8]$, and this may be due to high priced funds i.e. high financing cost which is a major obstacle in Ghana. Financing cost is defined to mean factors that affect the cost of funds directly. According to the businessdictionary.com [48], financing cost in general, means price of obtaining debt (loans and bonds) and equity (common stock) capital. According to Jongwanich and Kohpaiboon [9] the user cost of capital can be grouped into three: - interest rate, depreciation, and the price of obtaining the capital stock. Also, according to Baum and Tolbert [10] interest, exchange, inflation rates among other macroeconomic factors are price i.e. cost. This study supports this reasoning. Consequently, in this study costs incurred to obtain funds or finance are interest rate, exchange rate, and inflation rate: financing cost. But, financing cost has been a major impediment to private investment due to the changes in the cost variables such as interest rate, exchange rate, and inflation rate etc. The implication of high cost of financing is that private investors are discouraged from participating in investment activities. The response of the private sector to this challenge depends mainly on affordable cost of finance among other factors. Financing cost has come up as an important issue in private investment and therefore, noted to be an indispensable factor in private sector investment decisions. Hence, the effect of financing cost on private investment is of much concern to modern financial 
researchers and policy-makers.

The foremost objective of this research is to assess and analyze the impact of the various forms of financing cost factors independently on private investment in Ghana. In order to achieve this objective, the study identified relevant cost variables as well as other relevant non-cost variables that determine private investment, using the latter as control variables.

More specifically, the study pursued the following objectives:

$\mathrm{i}$ To find the relationship and the direction of causality between financing cost factors and private investment in Ghana over the long run.

ii To establish whether any of the variables used co-integrated with the dependent variable: Private Investment.

The importance of this study is to make beneficiaries of the study especially potential and prudential investors, business owners or enterprises in Ghana and beyond, know that a firm's success depends largely on its ability to secure low cost funds or raise affordable funds for its investment programs. Using the Johansen co-integration technique and the Error Correction Model, the study has brought to light how high cost funds hampers private investment in Ghana, so that appropriate measures could be taken to curb its spillover effect on economic growth and development.

The research has been organized in six main sections. Section one covers the introduction; section two provides a brief overview of domestic private investment and foreign direct investment in Ghana. Section three reviews and situates theoretical and empirical literature on the study. Section four outlines the methodology and data used for the study. Section five presents the results and analysis of the findings from the study. Finally, section six concludes and gives policy recommendations.

\section{Brief Overview of Private Investment and FDI in Ghana}

\section{Domestic Private Investment in Ghana}

Ghana began its journey to sustainable growth and development through rapid industrialization in the 1960s, using variety of control measures and state intervention. During the 1970s and early 1980s, economic policies were simultaneously not conducive to investment. This period was also, characterized mainly by political instability; inconsistent economic and public policies; and economic decline [11]. The economic and public policies were likewise not conducive for private investment programs in Ghana. Moreover, by the perception of uncertainty in political and economic environment, the picture of private investment in Ghana over the years seemed gloomy. Private sector investors were deterred because of risk in investment due to inappropriate measures, programs and institutions of the economy as well as financial setbacks to a large extent. Quite recently, the assurance of operating in secured and safe environment has stimulated private sector investors both foreigners and indigenes to open more and new businesses. Consequently, the private investment drive seems to be on course notwithstanding certain challenges evidently inherent in the economy.

\section{Foreign Direct Investment (FDI) in Ghana}

Foreign Direct Investment (FDI) has been viewed as a major stimulus to economic growth in developing countries including Ghana. Its ability to deal with two major obstacles, namely, shortages of financial resources; and technology and skills have made it the centre of attention for policy makers in low-income countries in particular. It can also, impact the host economy through a variety of channels. Principally, it helps by adding to resources available for private investment and capital formation. The transfer of technology, skills, innovative capacity, organizational and managerial practices between countries is also enhanced through the activities of foreign direct investors [12].

\section{Review of Literature}

\section{Theoretical Literature}

The theories of investment date back to the days of John Maynard Keynes. Keynes [13], he was the first to call attention to the concept (existence) of an independent investment function in the economy. A central feature of the Keynesian analysis is the observation that although savings and investment must be identical, ex-post savings and investment decisions are in general taken by different decision makers and there is no reason why ex-ante savings should equal ex-ante investment. He considered investment as a function of the prospective marginal efficiency of capital in relation to a given level of interest rate reflecting the opportunity cost of the invested capital. $\mathrm{He}$ argued that investment is worth undertaking if the present value of the future income stream from a given level of capital investment is equal to or greater than the initial cost of capital. Furthermore, he pointed out the intrinsic volatility of private investment as a consequence of the underlying uncertainty associated with the expected returns on investment. Investment theory has been in rapid evolution after Keynes' original formulation.

The next phase in the evolution of investment theory gave rise to the accelerator theory. The accelerator models of investment have their origin in the works by $[14,15]$. The models generally take the empirical form of the linear relation of current net investment to current and past changes in output. The naïve accelerator theory of investment posits that investment responds to changing demand conditions. It postulates a linear relationship 
between investment and output. The basic assumption of the model is that the desired capital stock at any point in time is a constant multiple of output at that time. That is $\mathrm{K}^{*}$ $=\alpha \mathrm{Y}$, where $\mathrm{K}^{*}$ is the desired capital stock, $\alpha$ is a constant multiple of output and $\mathrm{Y}$ is output. In the naïve accelerator model, expectations, profitability and capital cost play no role in the determination of investment. The theory is based on stable optimal capital-output ratio. According to the theory, as output exogenously increases, firms immediately raise their capital stock, that is, invest sufficiently to ensure that the capital-output ratio remain unchanged. Hence given an incremental capital-output ratio, it will be possible to calculate the investment level required to achieve a given targeted level of output growth. The problems with this theory are it simplistic assumptions that there is a fixed ratio of desired capital stock to output and the unrealistic assumption that the capital stock instantaneously adjusts to its optimal level, failing to recognize the high cost of adjustment and the time lag necessary for acquiring capital goods.

Following the limitations of the naïve accelerator theory, the flexible accelerator theory emerged. The naïve accelerator theory was modified to what became known as flexible accelerator principle of investment. A more general form of the accelerator model is the flexible accelerator model. The basic notion behind this model is that the larger the gap between the existing capital stock and the desired capital stock, the greater a firm's rate of investment. Unlike the naïve accelerator theory, the flexible accelerator theory postulates that firms do not instantaneously adjust their existing capital stock to the desired capital stock because of uncertainties and various adjustment costs. Rather, what happens is that once a 'shock' to output occurs, firms gradually adjust their level of capital with the aim of re-establishing the optimal capital-output ratio. The theory therefore asserts that the gap between the existing capital stock and desired capital stock determines investment. The larger this gap, the greater the firm's rate of investment as firms attempt to close the gap in each period. Consequently, the net investment equation could be formulated as : $\mathrm{I}=\delta\left(\mathrm{K}^{*}-\mathrm{K}-1\right)$, where I represents net investment, $\mathrm{K}^{*}$ is the desired capital stock, $\mathrm{K}-1$ denotes last periods capital stock and $\delta$ is the partial adjustment coefficient, which shows how fast the gap $\mathrm{K}^{*}$ - K-1 will be closed. A large coefficient of adjustment depicts a faster pace of closing the gap between desired capital stock and the actual stock. In the flexible accelerator model, output, internal funds, cost of external financing and other relevant variables are included as determinants of the desired capital stock. The model may be transformed into a theory of investment behaviour by adding a specification of desired capital stock and a theory of replacement investment. While desired capital stock is proportional to output in the flexible accelerator model, the desired capital stock, in the alternative models depends on capacity utilization, internal funds, the cost of external finance and other variables (ibid).

The neoclassical theory of investment (version of the flexible accelerator theory), which was pioneered by Jorgenson [16-18], postulates that output levels and user cost of capital are the key determinants of investment. In this approach, the desired or optimal capital stock is proportional to output and the user cost of capital. The user cost of capital in turn is determined by the price of capital goods, the real rate of interest, depreciation rate and the tax structure. In the neoclassical theory, the firm is assumed to reach an equilibrium level of capital stock when the value of the marginal value product of capital equals it user cost. The neoclassical investment theory suggests that the growth rate of real GDP positively influences private investment [19-21]. Also theory posits that private investment is negatively related to interest rate as high interest rate is believed to discourage investment by raising user cost of capital and the growth rate of real GDP positively influences investment [3]. The neoclassical model of investment is based on the assumption of perfect capital market with little or no government intervention. These may hold for developed countries but not for developing countries, these assumptions are unrealistic as financial markets in developing countries are characterized by imperfections. Imperfection in the credit markets is believed to prevent firms from borrowing as much as they wish, thereby constraining investment.

In summary, at a higher lending interest rate therefore, the net profit of most projects will be lower or even negative thereby discouraging potential investors from investing. Symmetrically, at a lower lending interest rate level, more projects will become profitable, encouraging investors to invest more. However, McKinnon-Shaw [22, 23] suggest that there could be positive relationship between investment and real rate of interest, because higher real rate of interest would increase savings, volume of domestic credit will increase and as a result equilibrium investment be higher. This hypothesis, known as McKinnon and Shaw hypothesis, is based on assumption that availability of funds is the main constraint on investment rather than cost of funds. At a higher deposit interest rate level, more funds will be mobilized and accessed, thereby encouraging investors to invest more. Thus, while it may be true that demand for investment declines with the rise in the real rate of interest, realized investment actually increases because of the greater availability of funds.

More recent literature has introduced an element of uncertainty into investment theory due to irreversible investment [24]. The argument is that since capital goods are often firm-specific and has a low resale value; disinvestment is more costly than positive investment. $\mathrm{He}$ argues that the net present value rule of investment, when the value of a unit of capital is at least as large as its cost must be modified when there is an irreversible investment because when an investment is made, the firm cannot 
disinvest should market conditions change adversely. This lost option value is an opportunity cost that must be included as part of the cost. Accordingly, "the value of the unit must exceed the purchase and installation cost, by an amount equal to the value of keeping the investment option active" [24]. The theory of investment irreversibility suggests that the cost of investing in machinery and equipment is usually not recovered by a future resale [3]. Three major sources of uncertainty have been identified: unstable macroeconomic environment, unstable policy environment and external shocks.

\section{Empirical Literature}

Hadjimichael and Ghura [25] carried out an empirical analysis on private investment performance of thirty-two (32) African countries over the period 1986 to 1992, using a specification that includes the variability of inflation and the real exchange rate as measures of economic uncertainty. Their estimation results show that either measures of macroeconomic uncertainty has a strong adverse impact on investment. Ghura and Greenes [26] had similar results when they studied the macroeconomic performance in thirty-three (33) sub-Saharan African countries during 1987 to 1992. They conclude that real exchange rate instability has a strong adverse impact on the (total) investment/GDP ratio. In support, Solimano [27], his paper on how private investment reacts to changing macroeconomic conditions in Chile, shows that the instability of the real exchange rate has a significant negative effect on private investment. Serven and Solimano [28] investigating the role of some factors in the observed performance of investment in developing countries using a pooled cross-section-time series data for a group of fifteen (15) developing countries, find that inflation instability index and the real exchange rate instability index (measures of instability) have negative impact on private investment. Aryeetey [29] concludes that the poor growth in private investment in Ghana might be attributed to the perception of uncertainty in the political and economic environment since 1982. He observes that the uncertainty is derived from the low credibility of government, as it has been unable to assure investors that earlier decisions that showed a bias against private wealth will not be repeated. Private investment impacted by macroeconomic variables like real exchange rates and interest rates were identified as important to investment decisions.

A study by [30] examined the determinants of private sector investment for Kenya using OLS and data over the period 1964-1996. The results indicate that both the availability of credit and foreign exchange exert significantly positive effects on private investment. Private investment however, was adversely affected by the stock of debt and exchange rate depreciation while public investment crowded in private investment, contrasting the results of Were for Kenya where the author in 2001 finds interest rate to be less important in determining the level of private investment in Kenya and also, establishes crowding-out.

Asante [7] in a study to analyze the determinant of private investment in Ghana for the period 1970-1992, using times series analysis, cross sectional analysis and the ordinary least square (OLS), finds that the overall measure of macroeconomic instability has been a major hindrance to private investment; while credit to the private sector has a positive and significant effect on private investment; public investment was complementary to private investment; the real GDP growth shows a positive sign in all the trials; but military takeovers created a climate hostile to private investment. Based on the findings, the author recommended that policies that address only some components of macroeconomic instability may not be enough to revive private investment. The financial determinants of domestic investment in Sub-Saharan Africa were examined by [31]. The study employed panel data for thirty countries over the period 1970-1995. The results indicate a positive relationship between both total and private investment and three indicators of financial development, while credit to the public sector was negative and significantly related to investment. With regards to control variables used, the results show that investment was negatively related to the debt service, debt stock, the black market premium, and inflation, while domestic investment was positively related to per capita GDP growth and international trade flows.

The determinants of domestic investment in Africa was explored by [32], their findings show that macroeconomic factors such as fiscal deficit, domestic credit to the private sector, the real exchange rate, and macroeconomic uncertainty explain a substantial part of the feeble investment performance in the region. They further argue that low domestic investment is a problem not only because investment matters for growth, but also because low investment levels further weakens an entire economy. Badawi [33] in investing the impact of macroeconomic policies on private investment over the period 1969-1998, The results suggest that increase in interest rate has been deleterious to private investment, indicating that price of funds did matter for private investors in Sudan.

Exploring promoting of investment in Africa, Anyanwu [1] documents that the reasons for poor performance of domestic investment could be mainly attributed to the following: low domestic resource mobilization; high degree of uncertainty; poor governance, corruption and low human capital development; unfavorable regulatory environment and poor infrastructure; small individual country market sizes; high dependence on primary commodities exports and increased competition; poor image abroad; shortage of foreign exchange, the burden of huge domestic and external debt; and underdeveloped capital markets with high volatility and home bias by 
foreign investors.

Frimpong and Marbuah [8] examined factors that have either stimulated or dampened private sector investment in Ghana. Employing co-integration and error correction techniques within an ARDL framework their results suggested that private investment is determined in the short-run by public investment, inflation, real interest rate, openness, real exchange rate and a regime of constitutional rule, while real output, inflation, external debt, real interest rate, openness and real exchange rate significantly influenced private investment response in the long-run. Akanbi [34] empirically examined the pattern of domestic investment in Nigeria using a neoclassical supply-side model and employed the Johansen estimation techniques over the period 1970 to 2006 . The results show that real output, user cost of capital, and the level of financial development and the governance indicators are significant determinants of domestic investment in Nigeria.

Fietas and Sinha [35] investigated constraints on investment and they find that; lower access to finance for start-ups and younger firms hamper business formation and hence productivity and growth; market failures in serving the needs of SMEs amount to inefficient financial intermediation whereby finance is not allocated to its most productive use; better access to finance enjoyed by foreign firms helps them expand more quickly than their domestic rivals; financial liberalization seems to facilitate the access of firms to credit, especially small ones, by reducing the institutional barriers and transaction costs in the market for credit; and a well-functioning commercial banking system plays a critical role for the development of the private sector by providing the investment that is needed to accelerate growth and reduce poverty.

It is instructive to note that even though private investment has attracted some attention in the literature, empirically it has not been explored exhaustively. The role of interest rates, exchange rates and inflation rates: financing cost in investment decisions is important. Thus any uncertainty or instability in interest, exchange and inflation rates will have serious consequences for investment decisions. The paper therefore, is different from the previous studies as it investigates financing cost and its impact on private sector investment activities in Ghana.

\section{Methodology and Data}

Following the empirical works done by Anyanwu [1], Asante [7], Frimpong and Marbuah [8], Ribeiro and Joanilio [36] and others, it is clear that private investment depends on three broad categories of variables: Keynesian, Neoclassical and Uncertainty variables.

\section{Data Type and Source}

The research covered the period of 1970-2010, and it made use of secondary data that were sourced from the
Bank of Ghana, International Financial Statistics of the IMF, and World statistical tables of the World Bank. Data on interest (lending rate), inflation (CPI, base year 1997) and exchange rates were obtained from the Bank of Ghana and International Financial Statistics of IMF, each covering the above stated period. Data on external debt was obtained from the World Bank-World debt tables for the period of 1970-2010. Data on output- real GDP (base year 1993) was obtained from the Bank of Ghana, for the period 1970-2010. Data on credit to the private sector was obtained from International Financial Statistics for the period under study. Finally, data on private investment (using private capital formation as proxy) and public investment (using government capital expenditure \% GDP as proxy) was also obtained from International Financial Statistics for the period 1970-2010.

Description and justification of independent variables used:

i $\quad$ INTR $=$ Interest rate

In the model, the interest rate used is a year-on-year of the annual percentage interest rate produced by the Bank of Ghana, which is the lending interest rate charged by commercial banks. According to the neoclassical theory Jorgenson [18] interest rate is expected to have negative influence on investment. It posits that private investment is negatively related to interest rate as high interest rate is believed to discourage investment by raising user cost of capital. Also, excessive government borrowing crowds out private borrowing and investing by forcing up interest rates and choking off private sector investment [37, 38]. However, McKinnon (22) and Shaw (23) suggest that there could be positive relationship between investment and interest rate; because higher real rate of interest would increase savings, volume of domestic credit will increase and as a result equilibrium investment will be higher. Therefore, interest rate is expected to have either negative or positive influence on private investment.

\section{ii $\quad \mathrm{NFL}=$ Inflation rate}

In this model, the rate of inflation has also been included, and it is measured by consumer price index. The rate at which general prices of goods and services which changes over time (consumer price index) has been a very relevant variable that determines cost of financing investment. Inflation is believed to be an important factor that influences investment decisions in any economy. Moreover, inflation pressures raises interest rate and relative instability in foreign exchange rates. Besides, this may result into change in real income of the economy as a whole, thereby altering the production capacity. According to Pindyck [24] rising inflation is a major cause of price uncertainty in an economy. Inflation is therefore expected to 
have an inverse relationship with private investment.

iii $\mathrm{EXR}=$ Exchange rate

Exchange rate is the rate at which domestic currency can be converted into foreign currency and vice versa. The exchange rate used in this study is the cedi / dollar rate from Bank of Ghana. As the exchange rate fluctuates, the domestic currency value of goods priced in foreign currency similarly fluctuates. The exchange rate influences the relative prices of foreign and domestic investment of goods and services, and which, when rising, augment total purchasing power of business income [38]. Also, Chibber and Mansoor [39] argue that a real depreciation acts as an adverse supply shock in the "production" of investment goods. A change in currency value changes the real costs of purchasing imported capital goods, the profitability of the private sector is affected and possibly causing investment to retard. The effect of the exchange rate on private investment is hazardous. The exchange rate is therefore expected to have negative influence on investment.

$\mathrm{PI}=$ Public or Government Investment

Government or Public sector investment has been found to affect private investment, although its impact remains ambiguous. For instance public investment can boost private investment by increasing private returns through the provision of infrastructure (Communication, transports, energy, etc.). Conversely, public investment may crowd out private investment if the public expenditure was made in especially non-developmental programs such as on defense and debt servicing. Hence it can impact private investment in either ways.

$\mathrm{v}$ CPS $=$ Credit to the private sector

Another important factor that affects the private sector investment is credit availability. Due to underdeveloped capital markets and financial intermediation in developing economies, thus the absence of long-term financing and the futures market, bank loans and external borrowing may be the only sources of credit available for private sector investment financing. A positive relationship is expected, the higher the credit made available to the private sector the higher the level of investment.

vi Output growth $=$ real GDP $=$ RGDP

The real gross domestic product (RGDP) is used as a proxy for output growth. Real GDP is expected to induce the private investor to invest more, hence expected to have a positive impact on private investment. The neoclassical theory of investment, based on the work of Jorgenson [16], treats the value of the capital stock desired by a competitive enterprise as a positive function of its output level. Accelerator theory also suggests that as demand or income increases in an economy, so does the investment made by firms. Furthermore, when demand levels result in an excess in demand, firms increase investment to match demand. Accordingly, a positive relationship is expected between output (proxied by real GDP) and private investment.

vii $\quad \mathrm{EXD}=$ External debt.

A further impediment to private investment is external debt of the nation. High debt levels divert the resources previously used to finance the local private sector, towards debt payments and charges being transferred abroad. Stated differently, high debt levels divert the resources previously used to finance local companies toward service payments and charges being transferred abroad. The higher the debt is, the lower the private investment and vice versa. Therefore, an inverse relationship is expected between external debt and private investment.

\section{Model Specification}

The model specification of this study follows that of Ribeiro and Joanilio [36], with little modification in terms of the cost factors and the non-cost factors of private investment. The modified model is given as in equation (1):

$$
\begin{aligned}
\text { PINV }= & \beta_{0}+\beta_{2} \text { PI }+\beta_{3} \text { RGDP }+\beta_{4} \text { CPS }+\beta_{5} \text { INTR }+ \\
& \beta_{6} \text { EXR }+\beta_{7} \text { NFL }+\beta_{8} \text { EXD }+\varepsilon_{t}
\end{aligned}
$$

Where PINV is private investment, PI is public or government investment, RGDP is the real gross domestic product, CPS is the credit to the private sector, INTR is the real interest rate, EXR is the exchange rate, NFL is the inflation rate and EXD is the external debt. Where $\beta_{1}>0$, $\beta_{2}<0$ or $\beta_{2}>0, \beta_{3}>0, \beta_{4}>0, \beta_{5}<0$ or $\beta_{5}>0, \beta_{6}<0, \beta_{8}<$ 0 , are the coefficients of the explanatory variables in the model, whilst $\varepsilon_{\mathrm{t}}$ is the error term over the time span. Besides $>0$ and $<0$, indicate positive and negative coefficient having a direct or an inverse relationship with the PINV variable respectively. The private investment function derived is a variant of the flexible accelerator principle designed to account for the objective of the study.

\section{Econometric Techniques for Estimation}

To ensure that the model conforms to standards and renders the results reliable, the following diagnostic tests were carried out to assess the performance of the model. These diagnostic tests include pairwise correlation test (correlation matrix of dependent and independent variables), autocorrelation test, Jarque-Bera Normality test, Heteroscedasticity test and Ramsey reset test. In addition, 
stability tests were also performed to ascertain the stability or otherwise of the models using the Cumulative Sum (CUSUM), Cumulative Sum of Squares (CUSUM Square) and Recursive Residual tests. The Augmented DickeyFuller (ADF) test was employed to determine the level or degree of integration of the variables-how many times the variables need to be differenced to attain stationarity. The study employed the Johansen-Juselius [40] multivariate cointegration technique for estimation of the long run private investment function. Furthermore, the Error Correction Model (ECM) was constructed in order to appreciate the short-run dynamics of the private investment function.

\section{Empirical Results and Analysis}

\section{Diagnostic Test Results}

Table 1. The summary of the diagnostic statistics

\begin{tabular}{|c|c|c|}
\hline Normality Jarque - Bera & $1.122033[0.570629]$ \\
\hline Breusch - Godfrey Serial Correlation LM Test & \\
\hline & F - Statistics & $1.097045[0.351437]$ \\
\hline & TR $^{2}$ & $3.083359[0.214021]$ \\
\hline White Heteroscedasticity Test (no cross products) & \\
\hline & F - Statistics & $1.352623[0.275284]$ \\
\hline & TR $^{2}$ & $20.04934[0.271713]$ \\
\hline Ramsey Reset Test & F - Statistics & $1.168735[0.290867]$ \\
\hline ARCH (3) & F - Statistics & $0.843030[0.480477]$ \\
\hline
\end{tabular}

NB: Figures in square brackets are significance probabilities

The Diagnostic tests results indicate that the specification is correct. Thus, the statistical properties of the error correction model conform to standard and render the results reliable. In addition, the tests results show that there are no autocorrelation, no heteroscedasticity and the errors are normally distributed. Thus, the index of each of the independent variables influences Ghana's long run private investment function over the period under study. The low probability associated with the F-test for the overall regression also lends credence to the short run model. The CUSUM, CUSUM of Squares and Recursive residual tests of stability confirm that the estimated model is stable as shown in Figures 1, 2 and 3 below.

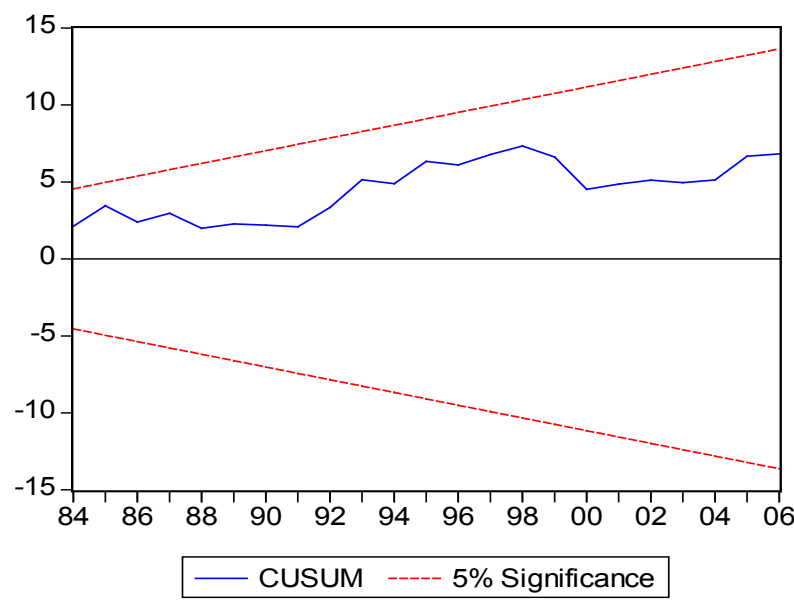

Figure 1. CUSUM Test for Stability

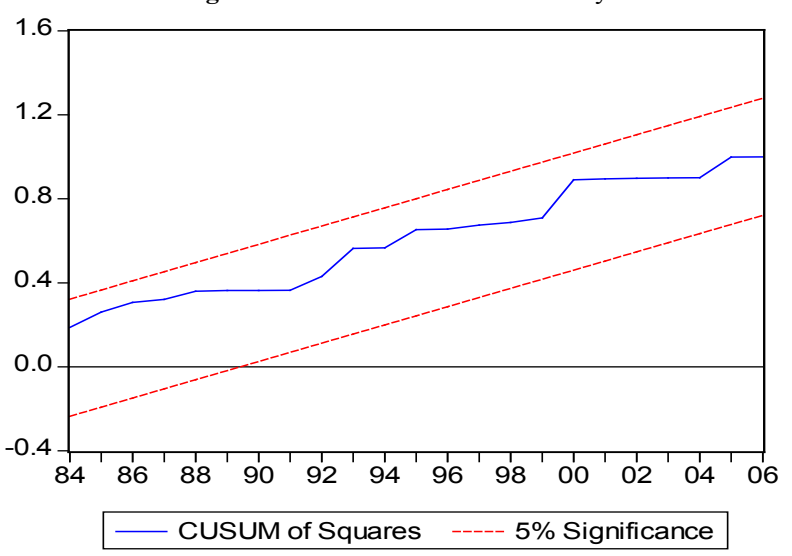

Figure 2. CUSUM square Test for Stability

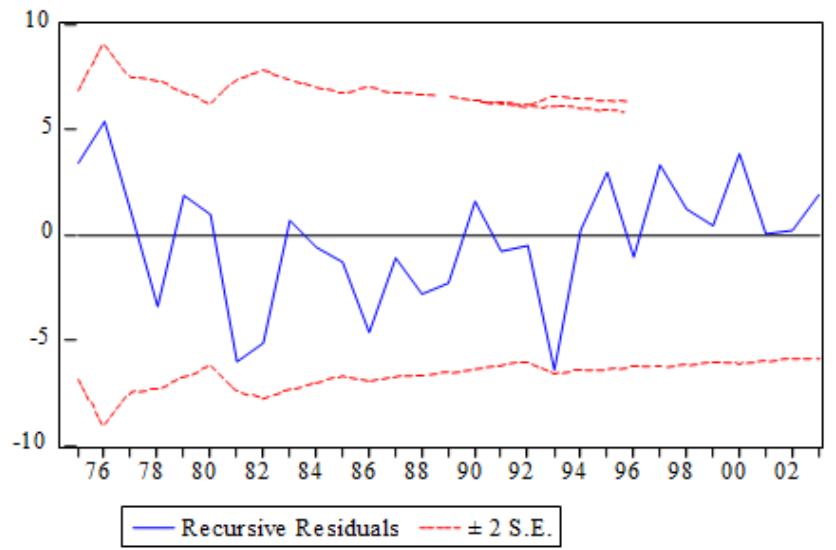

Figure 3. Recursive Residual Test for Stability

Table 2. Correlation Matrix of Dependent (PINV) and Independent Variables Results:

\begin{tabular}{|c|c|c|c|c|c|c|c|c|}
\hline & PINV & PI & RGDP & EXD & CPS & INTR & NFL & EXR \\
\hline PINV & 1 & & & & & & & \\
\hline PI & 0.4622 & 1 & & & & & & \\
\hline RGDP & 0.6503 & 0.5051 & 1 & & & & & \\
\hline EXD & -0.4495 & 0.9969 & 0.4889 & 1 & & & & \\
\hline CPS & 0.6705 & 0.5067 & 0.8611 & 0.4926 & 1 & & & \\
\hline INTR & -0.5193 & 0.4211 & 0.6417 & 0.3734 & 0.3952 & 1 & & \\
\hline NFL & -0.6751 & 0.4176 & -0.7927 & -0.4008 & 0.5943 & -0.7514 & 1 & \\
\hline EXR & -0.6122 & 0.6327 & 0.9502 & -0.6185 & 0.8621 & 0.5357 & -0.6978 & 1 \\
\hline
\end{tabular}

Source: computed from data collected; significance at $5 \%$ 
A look at the correlation matrix (table 1) shows that for Ghana, the relationship between private investment and all the cost variables are strong, with the NFL (-0.6751) having the strongest negative correlation with PINV. On the other hand, with the non-cost variables, except for external debt, all had positive relationship with PINV, with the CPS (0.6705) having the strongest positive correlation. In general, the positive coefficients exhibit direct relationship with the PINV variable, whilst those with the negative coefficients exhibit inverse relationship with PINV.

\section{Johansen Co-integration Results}

Table 3. Long-Run Co-integration Results

\begin{tabular}{|c|c|c|c|}
\hline Variable & Coefficient & Standard Error & t-statistics \\
\hline D(DPINV(-1)) & 1.0000 & - & 4.6296 \\
\hline D(DPI(-1)) & 0.0125 & 0.0027 & 2.5517 \\
\hline D(DRGDP(-1)) & 0.0074 & 0.0029 & 2.1603 \\
\hline D(DCPS(-1)) & 0.0283 & 0.0131 & 1.2857 \\
\hline D(DEXD(-1)) & 0.0063 & 0.0049 & 2.3053 \\
\hline D(DINTR(-1)) & 0.0219 & 0.0095 & 3.7308 \\
\hline D(DEXR(-1)) & 0.0194 & 0.0052 & 6.6939 \\
\hline D(DINFL(-1)) & 0.0328 & 0.0049 & 2.7710 \\
\hline C & 7.4185 & 2.6772 & \\
\hline
\end{tabular}

NB: The long-run results is significant when the absolute t-value is above two (2).

\section{Analysis of the Long Run Co-integration Results}

The econometric results show that after standardization, all the cost variables had negative and statistically significant impact on private investment in the long run, with the inflation variable having the strongest and highly significant impact.

The interest rate variable had a negative and significant impact on private investment in Ghana. Implying a $1 \%$ increase in interest rate leads to about $2.2 \%$ decrease in private investment in the long run. This confirms as in Neo-Classical theory that interest rate is a very important factor in any investment decision by the private sector. When the interest rate is increased by raising the cost of bank credit (lending interest rate) which is the main source of external financing for the private sector, there would be a decline in private investment. Moreover, the finding from this study is consistent with other empirical works like [20, 41], but at variance with other studies like [9, 42]. Consequently, the evidence from the regression results shows that high interest rate is indeed detrimental to private investment in Ghana. In addition, it is important to note that the spillover of large budget deficit with its associated high interest rate for private enterprises, can compel private investors to shift some of their portfolio into short-term activities such as purchases of treasury bills, due to high yield and safety. Hence, the monetization of budget deficit crowds out private investment by attracting investible funds from business activities into treasury bills. Also, large budget deficit with no check and balance on government expenditure is an example of institutional weakness. This thinking is in line with Heim [38].

It can also be seen from the results that exchange rate is significantly and negatively related to private investment in the long run. As a $1 \%$ increase in exchange rate would cause private investment to decrease by $1.94 \%$. This finding is in line with the results obtained by Froot and Stein [43] as well as Asante [7] which also finds a negative relationship between exchange rate and private investment. However, the result is contrary to the empirical work of Jongwanich and Kohpaiboon [9]. This negative effect can be explained by the fact that a real depreciation raises the cost of imported capital goods and since a large chunk of investment goods in Ghana are imported; domestic private investment would be expected to fall with real depreciation. Also, the findings indicated that the effect of inflation was the strongest; it was negatively related to private investment and was significant. The result shows that a $1 \%$ increase in inflation would lead to a drastic fall in private investment by $3.28 \%$. Inflation rates are noted to be an indicator of macroeconomic instability, which can have adverse impact on private investment. High and unpredictable inflation distorts the information content of relative prices, reduces the average maturity of commercial lending, and increases the riskiness of longer-term investment project. A high rate of inflation also, tends to discourage private savings and investment. Furthermore, the strong impact of the inflation rate variable supports the theoretical fact that inflation rate is a major hindrance to private investment in the long run. The result of this study is consistent with many empirical findings like [9,44], but it is inconsistent with Ndikumana [31]. Also, this implies that a country's ability to control inflation is very important in making investment decisions particularly in the long-run. 
Similarly, the control variables also impacted on private investment as explained below:

Public or government investment variable has a positive and highly significant relationship with the rate of private investment. This result means that a $1 \%$ increase in public investment would lead to $1.25 \%$ increase in private investment all things being equal. This positive relationship suggests complementarity between the public investment and private investment. Again this result is similar to the findings of Khan and Khan [41]. The results also show that output i.e. Real GDP has a positive and significant impact on private investment in the long run. This shows that a $1 \%$ increase in real GDP will lead to about $0.74 \%$ increase in private investment. The accelerator model suggests a positive relationship between changes in aggregate demand and real output growth, which investors attempt to satisfy. Increased output may also mean increased savings that can be used to finance domestic investment [45]. This result is similar to findings of [7, 20, 33] among others, who also find private investment to be positively related to real output (real GDP). Moreover, the result indicates that in the long run, credit to the private sector has a positive and significant impact on private investment activities in Ghana. The results show that $1 \%$ increase in credit to the private sector would improve private investment in Ghana by about $2.83 \%$. Bank credit remains the most important source of investment financing among private enterprises in developing countries including Ghana. It is therefore very important to encourage financial institutions to increase their credit facilities to the private sector especially the productive sectors of the private sector. The direct impact of credit availability on private investment is confirmed in several empirical studies including that of Asante [7] and Badawi [33]. The results also indicate that high external debt has a negative impact on private investment in Ghana, but it is not significant in the long run. The empirical findings indicate that a $1 \%$ increase in external debt may cause private investment to fall by $0.63 \%$. The results confirm the findings of Greene \& Villanueva [20]. The results confirm the findings of Greene \& Villanueva [20]. A high external debt signifies that part of the future returns on any investment must be used to service the existing stock of debt. Also, heavy debt over-hang reduces the incentive to invest because of the anticipated foreign tax on future income and returns on investment.

\section{The Error Correction Model Results}

Table 4. Results of the Error Correction Model (Private Investment Model) Dependent Variable: DPINV

Method: Least Squares

Sample (adjusted): 19722009

Included observations: 37 after adjustments

\begin{tabular}{|c|c|c|c|c|}
\hline Variable & Coefficient & Std. Error & t-Statistic & Prob. \\
\hline $\mathrm{C}$ & -2.328105 & 0.319211 & -7.293311 & 0.3022 \\
\hline DPINV & -0.012252 & 0.005113 & -2.396245 & 0.0024 \\
\hline DPINV(-1) & -0.001342 & 0.000412 & -3.257282 & 0.0032 \\
\hline DPI & -0.002842 & 0.001290 & -2.203107 & 0.0014 \\
\hline DPI(-1) & -0.011432 & 0.002724 & -4.196769 & 0.0207 \\
\hline DRGDP & 0.003354 & 0.002176 & 1.541360 & 0.0543 \\
\hline $\operatorname{DRGDP}(-1)$ & 0.000914 & 0.000425 & 2.150588 & 0.0056 \\
\hline DCPS & 0.010042 & 0.009462 & 1.061298 & 0.0761 \\
\hline DCPS(-1) & 0.001232 & 0.000361 & 3.412742 & 0.0023 \\
\hline DEXD & -0.002393 & 0.002182 & -1.096700 & 0.1304 \\
\hline $\operatorname{DEXD}(-1)$ & 0.001724 & 0.000891 & 1.934905 & 0.0284 \\
\hline DINTR & -0.025318 & 0.020321 & -1.245903 & 0.3245 \\
\hline DINTR(-1) & -0.050221 & 0.009314 & -5.391991 & 0.0004 \\
\hline DEXR & -0.020314 & 0.013225 & 1.536031 & 0.0379 \\
\hline $\operatorname{DEXR}(-1)$ & 0.012543 & 0.005052 & 2.482779 & 0.0074 \\
\hline DNFL & -0.004294 & 0.003794 & -1.131787 & 0.0633 \\
\hline DNFL(-1) & -0.031325 & 0.032163 & -0.973945 & 0.2107 \\
\hline $\operatorname{ECM}(-1)$ & -0.342615 & 0.087140 & -3.931776 & 0.0037 \\
\hline R-squared & 0.712412 & \multicolumn{2}{|c|}{ Mean dependent var } & 0.450854 \\
\hline Adjusted R-squared & 0.721129 & \multicolumn{2}{|c|}{ S.D. dependent var } & 0.054218 \\
\hline S.E. of regression & 0.114589 & \multicolumn{2}{|c|}{ Akaike info criterion } & 3.731611 \\
\hline Sum squared residual & 0.144436 & \multicolumn{2}{|c|}{ Schwarz criterion } & 3.941251 \\
\hline Log likelihood & -74.73465 & \multicolumn{2}{|c|}{ F-statistic } & 0.035138 \\
\hline Durbin-Watson stat & 2.025314 & \multicolumn{2}{|c|}{ Prob (F-statistic) } & 0.000211 \\
\hline
\end{tabular}

The Akaike Information Criterion (AIC) indicates that a lag length of one (1) was optimum.

This is consistent with the small sample size of the data. 


\section{Analysis of the Error Correction Model Results}

From the error correction model results, the error correction terms is correctly signed and significant with the absolute t-values above two (2). It has value of about 34\% percent indicating a low speed of adjustment to the long run equilibrium. There was a strong negative and highly significant impact of interest rate on private investment in the short run. As a $1 \%$ increase in the interest rate discouraged private investment by $5.02 \%$ in the short run. The strong impact of the interest rate variable supports the theoretical fact that interest rate is a major hindrance to private investment in the short run. This is consistent with the findings in previous studies [20,28], but inconsistent to the results of $[9,41]$. Also, the exchange rate (EXR) was positive and statistically significant, as a $1 \%$ depreciation of EXR (i.e., an increase in EXR) leads to an increase in private investment in the short run by $1.25 \%$. The positive and significant coefficient corresponding to EXR, may not reflect the nature of an import-led economy in Ghana. Moreover, in the short-run, the inflation rate was negative but insignificant. However, an increase in the variable by $1 \%$ leads to a decrease in private investment by $3.13 \%$. This result is consistent with the findings in Khan and Khan [41].

On the other hand, in the short run, the real GDP was positive and significant, thus an increase in output growth (real GDP) by $1 \%$ leads to an increase in private investment by $0.09 \%$. The positive and significant impact of output growth on private investment is consistent with the findings in previous studies [46]. However, in the short run, public investment (PI) had a negative and significant impact on private investment implying a crowd out of public investment. This means a $1 \%$ increase in the public investment variable, leads to a $1.4 \%$ reduction in private investment. This is consistent with the findings in previous empirical work like Ghani and Din [47]. This means that most of the public investment undertaken in the short run could have been for replacement purposes, rather than for expanding production capacity, raising a concern for the country's long-term growth sustainability. Besides, in the short run, the credit to the private sector variable (CPS) was positive and significant just like the long run. A $1 \%$ increase in CPS variable resulted in a $0.12 \%$ increase in private investment. This is consistent with the findings in previous empirical work of Jongwanich and Kohpaiboon [9]. Implying more credit made available, would ensure that potential and prudential investors can access credit adequately and help speed up the sluggish investment activities in the country. This is of importance especially for small and medium enterprises, which rely heavily on bank financing. Unsurprisingly, the external debt (EXD) was positive but insignificant, also in the short run. This means that a $1 \%$ increase in the EXD variable may lead to $0.17 \%$ increase in private investment, which is somehow contrary to the expected results. This suggests that the debt overhang has become less important.
This study therefore, establishes inspiring and original empirical evidence that all the financing cost variables i.e. interest rate, inflation rate, and exchange rate in the model have negative and significant impact on long run private investment in Ghana. Also, the assertion that there exists co-integration among the variables used and private investment in Ghana was likewise established on the grounds that the private investment variable, which is the dependent variable, co-integrated with all the independent variables used in the study.

\section{Conclusion and Policy Recommendations}

This research has provided original evidence that high cost of financing resulting from high interest, exchange and inflation rates impact adversely on private investment, and hence it is associated with the low private investment activities in Ghana. Thus, the study shows that flux in the components of cost of financing are a major hindrance to private investment activities or programs in Ghana. Of these, inflation and interest rates appeared to have had the strongest negative impact on private investment, whilst exchange rate had mild negative effect. Since, the private sector is the prime mover of any economy, for policies to improve private sector's response to investment programs, all the cost components must be addressed simultaneously. Policies to stabilize macroeconomic variables such as inflation, exchange and interest rates and well as cut down on government domestic borrowing for consumption purposes. For instance, governments, financial regulators or supervisors should explore the possibility of reducing the interest rate, but without running the risk of keeping it very low so as to discourage savings that provides loanable funds for investment. To do this effectively, requires specifying a range within which fluctuation in the interest rate would not have an adverse effect on private investment. Obviously, this calls for interest rate regulatory body on all commercial banks by the Central Bank. Besides, government must be discouraged from overspending its budget so as to refrain from financing its budget through the domestic banking system. There is therefore, the need for the government to be forced to spend within it allocated budget through law. To this end, a fiscal compliance law is recommended to be enacted so as to help compel the government operate within its allocated resources.

More importantly, necessary steps have to be taken to control inflation and stabilize exchange rate through the adoption of sound fiscal and monetary policies. As the present flexible exchange rate policy and possibly the failure of policies to ensure stability are likely to be the cause of the rampant variability in the exchange rates. To be able to check this variability, the Central Bank must have the capacity to intervene in the exchange rate market 
from time to time to curb the rapid devaluation of the currency, and also manage inflation. Such measures would bring exchange rates and deficit spending under control to relieve pressure on interest and inflation rates.

Likewise, credit availability is pivot to the private sector participation in investment activities. Policies should be put in place to encourage lending to especially the productive sectors of the private sector for their investment activities. Unfortunately, the limited credit available to the private sector is directed towards the unproductive sectors. To overcome this problem, the government must give tax incentives to financial institutions that finance risky investment such as those in Agriculture and manufacturing sectors. Also, government should increase public spending for infrastructure development in order to increase production capacity and incomes levels to augment real output; an economy with a large output of goods and services can better satisfy the demands of households, firms and the government. In addition, significantly positive real GDP growth signals a country's economic prospects and encourages foreign investors.

Besides, generally for developing nations, some policies adopted in the 1970s and early 1980s scared away private investors from participating in investment activities. It is therefore necessary for contemporary governments to give assurance to private investors that such situations will not arise again. Rather, there is the need to create an environment safe and conducive for private investment to thrive. Moreover, governments must come out with legislation that will protect private investments from any future seizures and forfeitures. Hence, legislative and administrative laws should be enacted to enhance confidence among private investors. Confidence is a necessary condition for private investment, and private investment is a necessary condition for economic growth and development. Additionally, the absence of well-developed or inefficient capital market apart from denying local companies the opportunity to raise long term capital for long-term investment, will also deny potential investors the opportunity to invest their excess funds in long term return projects, so efficient well-developed capital market is a necessary requirement for private investment to flourish.

Evidently, it is clear and important for policymakers in developing countries including Ghana, to assess how private investment respond to financing cost not only in designing long-term private investment development strategies and policies, but also in implementing shorter-term stabilization plans or programs. All told, in the long run, the cost of funds reduction path seems to be closely dependent on well-developed financial or credit markets, and on perspectives of macroeconomic stability.

\section{Appendices}

\section{Appendix A}

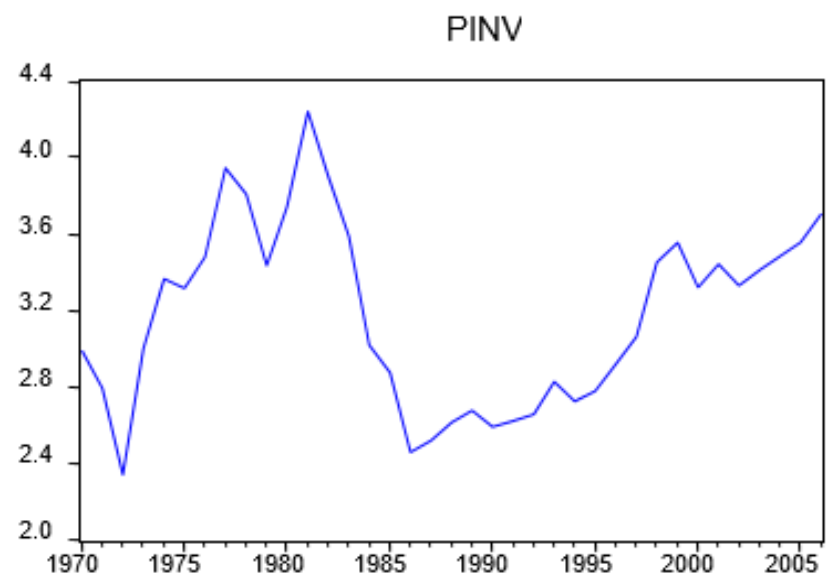

PI
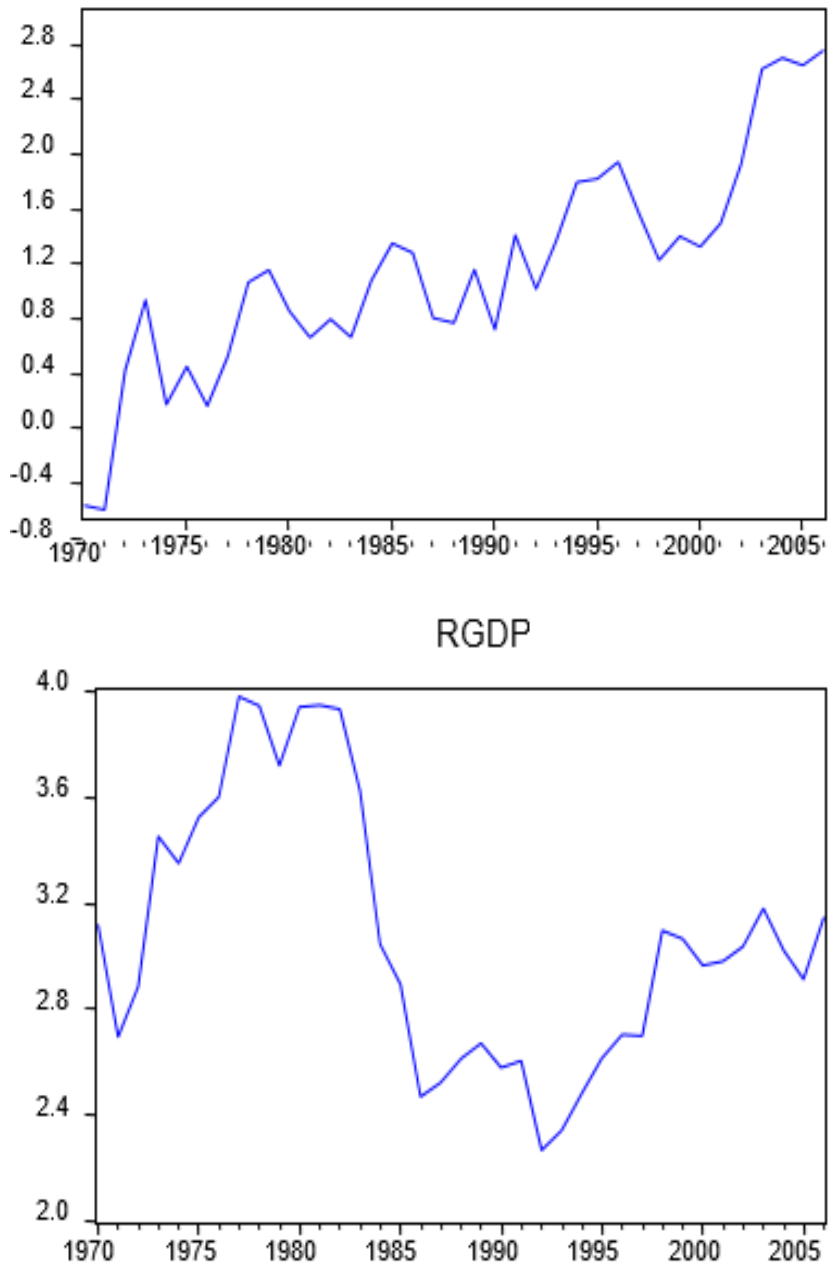

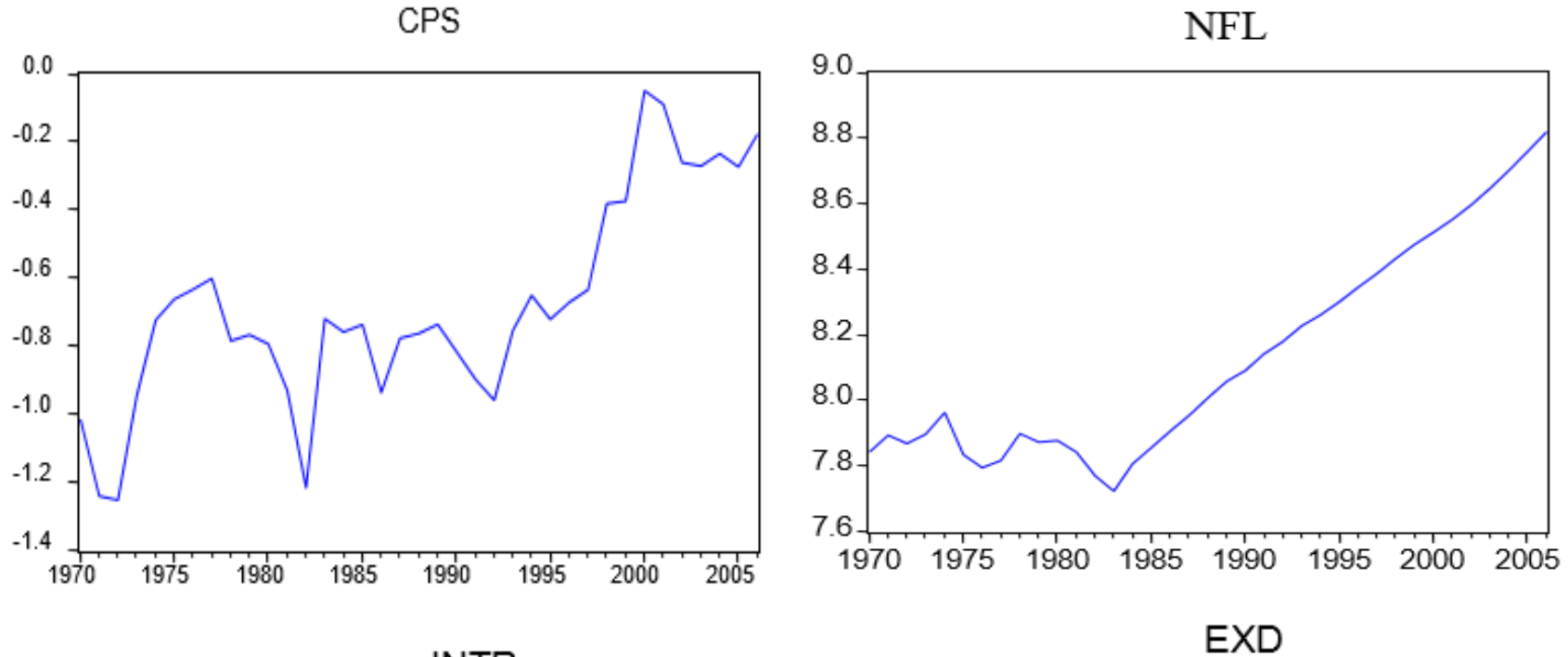

INTR
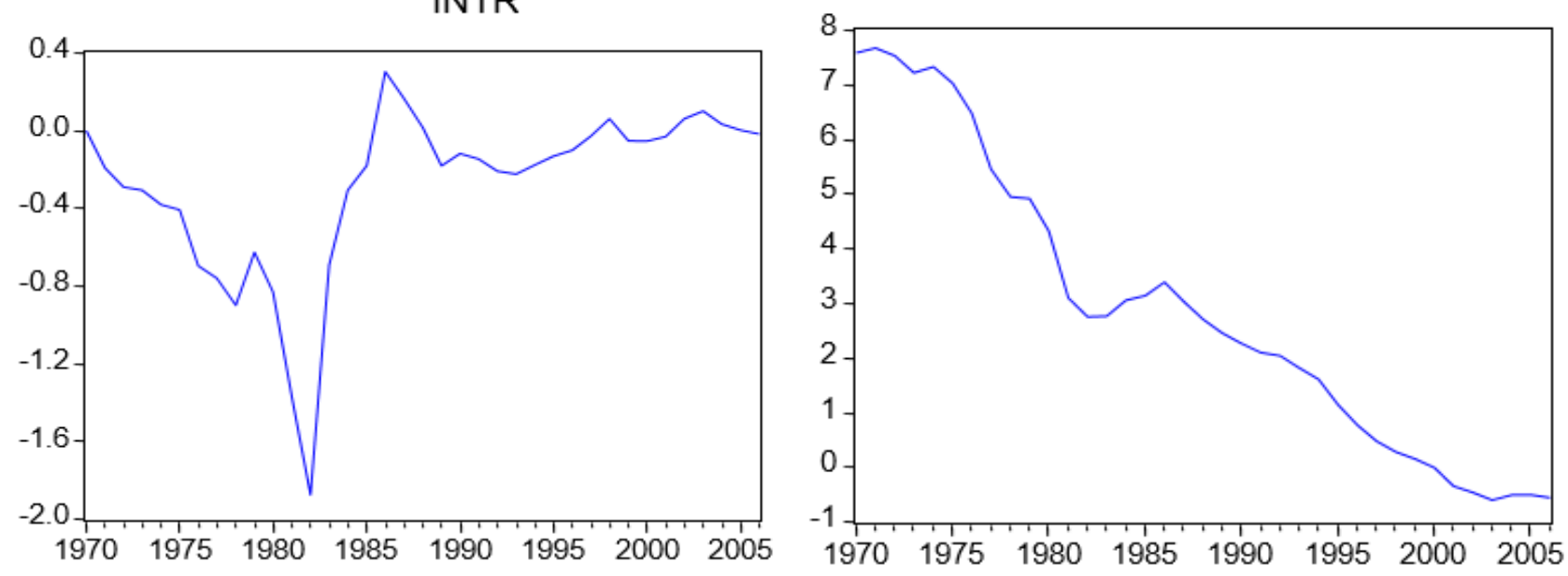

EXR

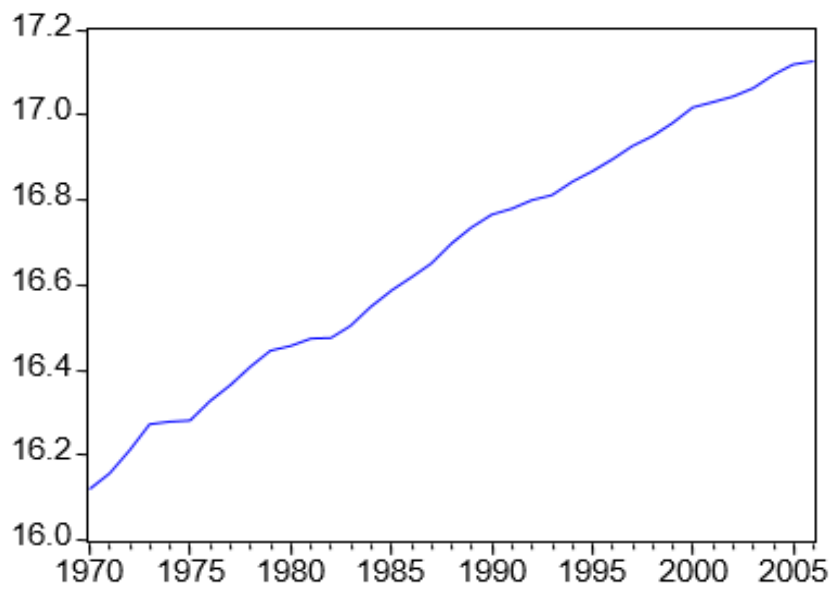

Source: graphed from data collected by the authors

Figure 4. Graphs of level of the variables

\section{Appendix B}

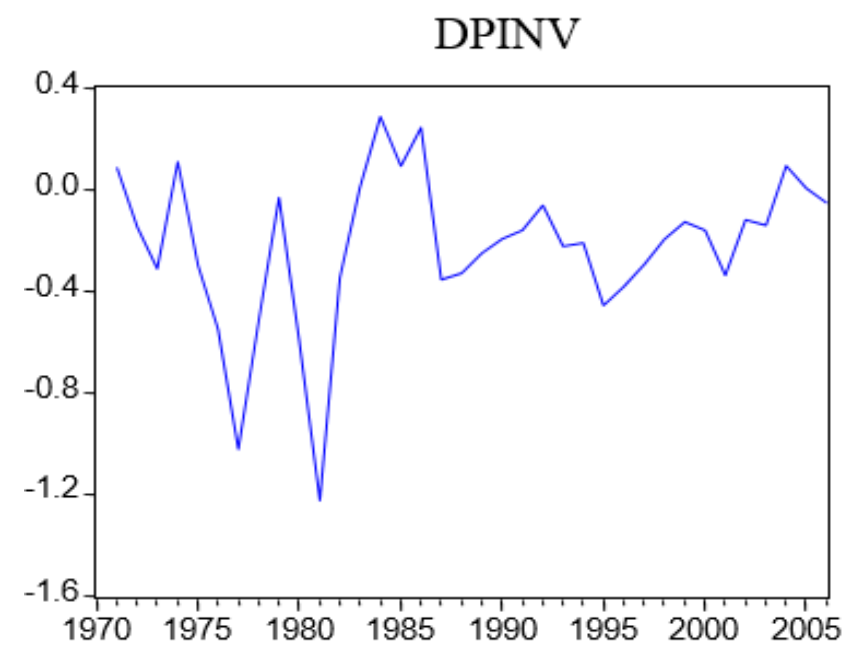


DPI

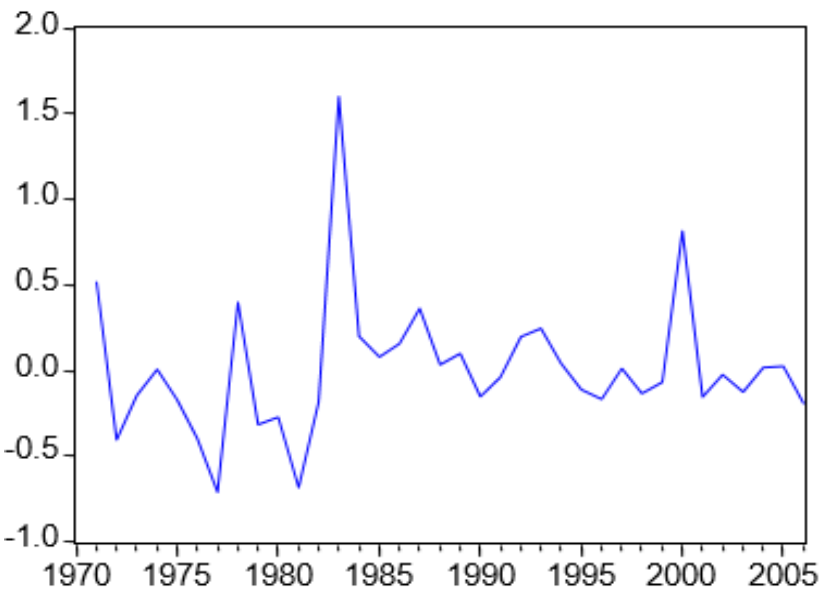

DRGDP

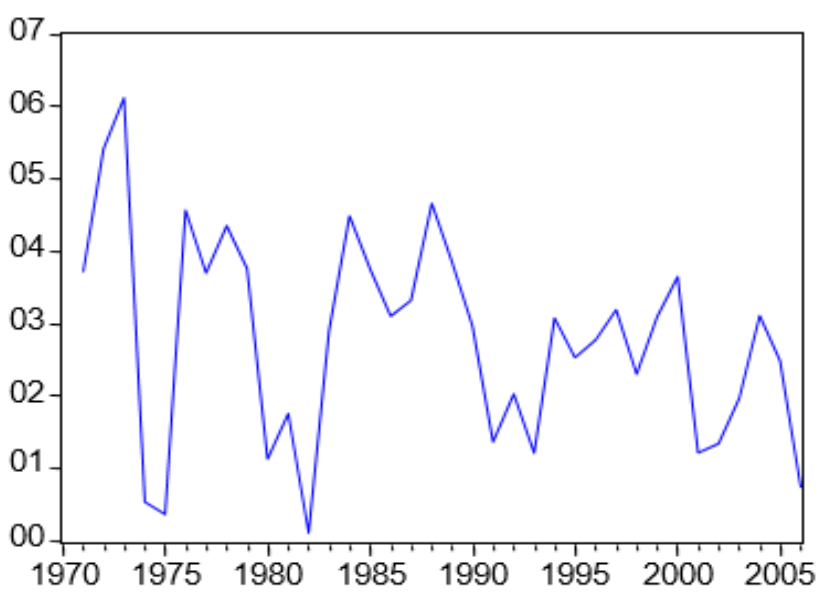

DCPS

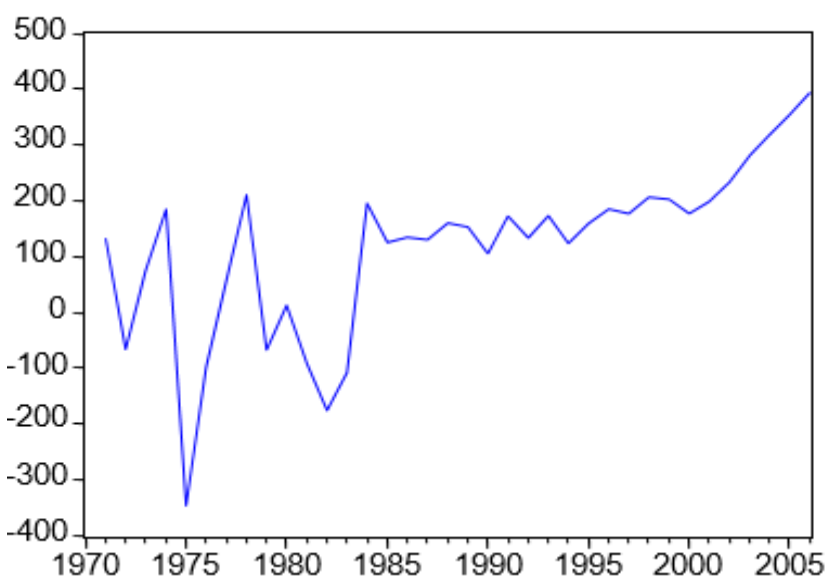

DINTR

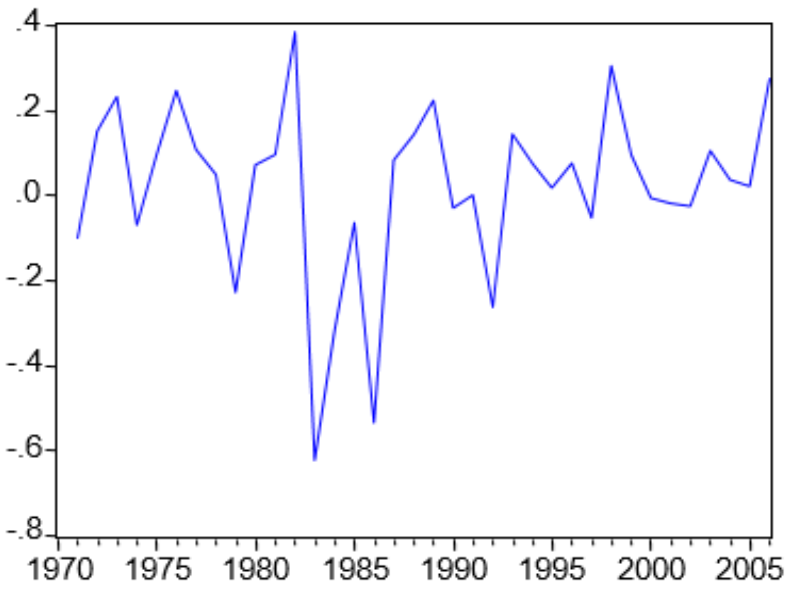

DEXR

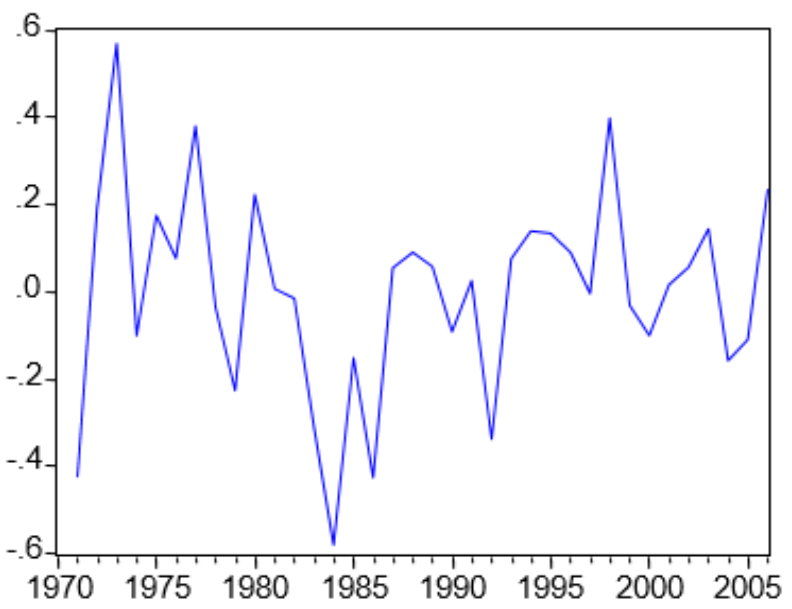

DNFL

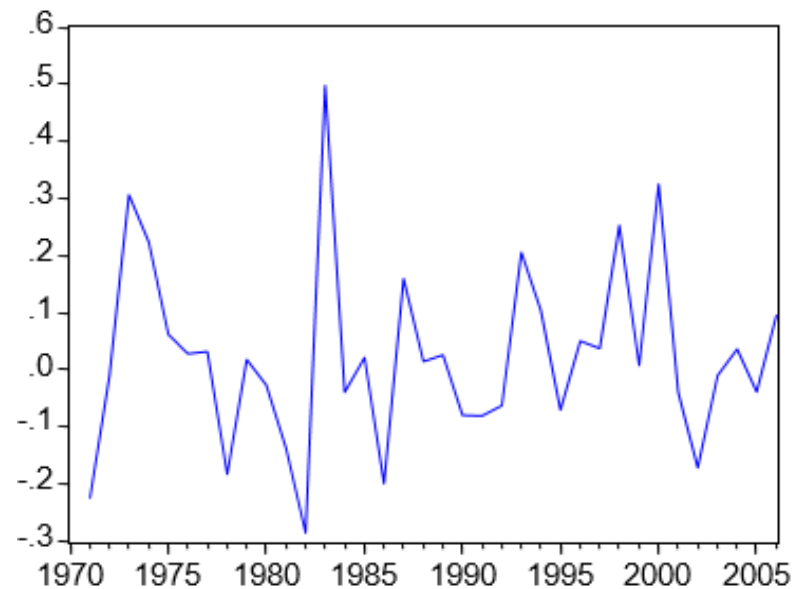




\section{DEXD}

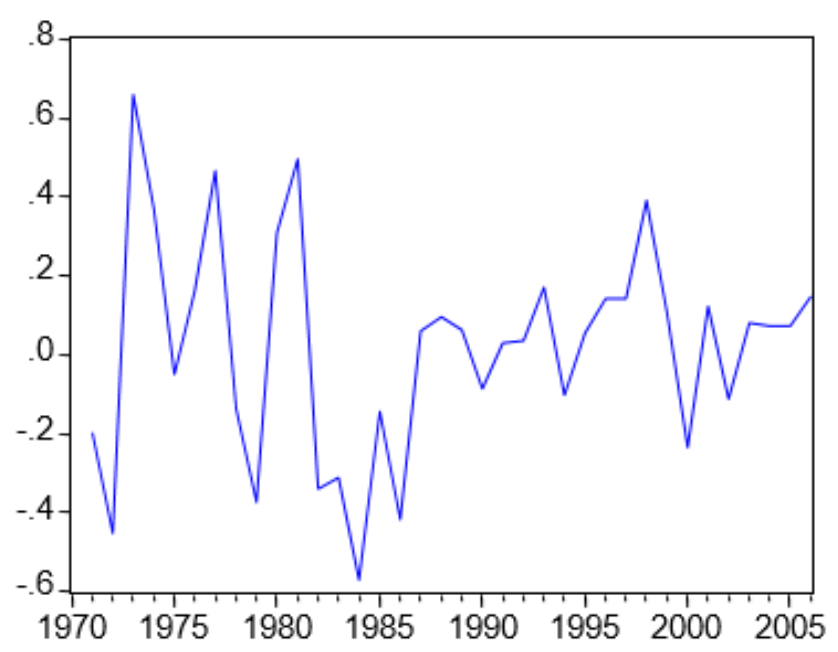

Source: graphed from data collected by authors

Figure 5. Graphs of first difference of variables

\section{Appendix C}

Unit Root Results

Table 5a. ADF Unit Root Test Results in Levels.

\begin{tabular}{|c|c|c|c|}
\hline VARIABLE & t-ADF value & Order of Integration & Number of lags \\
\hline PINV & -0.4049 & $\mathrm{I}(0)$ & 1 \\
\hline PI & -1.8000 & $\mathrm{I}(0)$ & 1 \\
\hline RGDP & -1.7896 & $\mathrm{I}(0)$ & 1 \\
\hline CPS & -0.5623 & $\mathrm{I}(0)$ & 1 \\
\hline EXD & -1.0374 & $\mathrm{I}(0)$ & 1 \\
\hline INTR & -1.1745 & $\mathrm{I}(0)$ & 1 \\
\hline EXR & -1.5059 & $\mathrm{I}(0)$ & 1 \\
\hline NFL & -1.6817 & $\mathrm{I}(0)$ & \\
\hline
\end{tabular}

Critical Values (ADF) in levels are:

$5 \%=-1.95$

$1 \%=-2.626$

Table 5b. ADF Unit Root Test Results in First Difference

\begin{tabular}{|c|c|c|c|}
\hline VARIABLE & t-ADF value & Order of Integration & Number of lags \\
\hline D(PINV) & $-7.663^{* *}$ & $\mathrm{I}(1)$ & 1 \\
\hline $\mathrm{D}(\mathrm{PI})$ & $-6.455^{* *}$ & $\mathrm{I}(1)$ & 1 \\
\hline $\mathrm{D}(\mathrm{RGDP})$ & $-2.8652^{* *}$ & $\mathrm{I}(1)$ & 1 \\
\hline $\mathrm{D}(\mathrm{CPS})$ & $-5.741^{* *}$ & $\mathrm{I}(1)$ & 1 \\
\hline $\mathrm{D}(\mathrm{EXD})$ & $-4.518^{* *}$ & $\mathrm{I}(1)$ & 1 \\
\hline $\mathrm{D}(\mathrm{INTR})$ & $-8.176^{* *}$ & $\mathrm{I}(1)$ & 1 \\
\hline $\mathrm{D}(\mathrm{EXR})$ & $-2.7345^{* *}$ & $\mathrm{I}(1)$ & 1 \\
\hline $\mathrm{D}(\mathrm{NFL})$ & $-10.98^{* *}$ & $\mathrm{I}(1)$ & 1 \\
\hline
\end{tabular}

Critical Values (ADF) in first difference are:

$5 \%=-1.95$

$1 \%=-2.626$

$\mathrm{NB}: * *=1 \%$ level of significance $*=5 \%$ level of significance
Table 6. The trace eigenvalue test statistics:

\begin{tabular}{|c|c|c|c|}
\hline $\begin{array}{c}\text { Trace test: } \\
\text { Eigenvalue }\end{array}$ & $\begin{array}{c}\text { Max-Eigen } \\
\text { statistic }\end{array}$ & $\begin{array}{c}1 \% \text { critical } \\
\text { value }\end{array}$ & $\begin{array}{c}\text { Hypothesized } \\
\text { No. of CE(s) }\end{array}$ \\
\hline 0.979815 & 145.23571 & 87.39755 & None * \\
\hline 0.825324 & 83.74878 & 76.38569 & At most ${ }^{*}$ \\
\hline 0.783216 & 62.84647 & 65.29746 & At most 2 \\
\hline 0.657139 & 41.77783 & 45.29846 & At most 3 \\
\hline 0.557677 & 32.07664 & 37.73728 & At most 4 \\
\hline 0.482138 & 24.41278 & 30.28746 & At most 5 \\
\hline 0.357126 & 15.24173 & 25.22947 & At most 6 \\
\hline 0.297315 & 10.42975 & 18.10935 & At most 7 \\
\hline
\end{tabular}

Source: computed from data collected by the authors

\section{REFERENCES}

[1] J. C. Anyanwu. Promoting of Investment in Africa, African Development Review, 18(1), 42-71, 2006.

[2] A. Hoeffler. Openness, Investment and Growth, Journal of African Economies, 10 (470-497), 2002.

[3] P. Acosta, A. Loza. Short run and Long run Determinants of Private Investment in Argentina, Journal of Applied Economics, 111(2), 389-406, 2005.

[4] C. Beddies. Investment, Capital Accumulation and Growth: Some Evidence from Gambia: 1964-1998”, IMF Working Paper 99/117, 1999.

[5] S. S. Everhart, M.A. Sumlinsk. Trends in Private Investment in Developing Countries Statistics for 1970-2000 and the Impact on Private Investment of Corruption and the Quality of Public Investment, IFC Discussion Paper No. 44, World Bank, Washington DC, 2002.

[6] D. Ghura, T. Hadjimichael. Growth in Sub-Saharan Africa", Staff Papers, International Monetary Fund, 43, September, 1996.

[7] Y. Asante. Determinants of Private Investment Behaviour in Ghana, The African Economic Research Consortium. Nairabi: AERC Research Paper 100, 2000.

[8] J. M. Frimpong, G. Marbuah. The determinants of private sector investment in Ghana: An ARDL approach, European Journal of Social Sciences, 15(2), 250-261, 2010.

[9] J. Jongwanich, A. Kohpaiboon. Private Investment: Trends and Determinants in Thailand, World Development Vol. 36, No. 10, pp. 1709-1724, 2008.

[10] W. C. Baum, S.M. Tolbert Investing in Development, Lessons of World Bank Experience, The World Bank, Oxford University Press, 1985.

[11] E. Aryeetey, J. Harrigan. Macroeconomic and Sectoral Development since 1970 in Aryeetey, E, Nissanke M and Harrigan J (eds), Economic Reforms in Ghana: The Miracle and Mirage, 2002.

[12] K. A. Baah-Nuakoh. Foreign Direct Investment and Sustainable Development: the case of Ghana, MPhil Thesis, 
University of Ghana, Legon, (2000).

[13] J. M. Keynes. The General Theory of Employment, Interest and Money, London: Macmillan, 1936.

[14] H. B. Chenery. Overcapacity and Acceleration Principle, Econometrica, 20: 1-28, 1952.

[15] L. M. Koyck. Distributed Lags and Investment Analysis, North Holland, Amsterdam, 1954.

[16] D. W. Jorgenson. Capital Theory and Investment Behavior, American Economic Review: 53: 247-59, 1963.

[17] D. W. Jorgenson. The Theory of Investment Behavior, in Determinants of Investment Behavior, ed, by R. Ferber (New York: National Bureau of Economic Research), pp. 129-55, 1967.

[18] D. W. Jorgenson. Econometric Studies of Investment Behavior: A Survey, Journal of Economic Literature (Nashville, Tennessee), Vol. 9, pp. 1111-47, 1971.

[19] D. Fielding. Adjustment, Trade Policy and Investment Slumps: Evidence from Africa, Journal of Development Economics, vol.52, pp. 121-137, 1997.

[20] J. E. Greene, and D. Villanueva. Private Investment in Developing Countries, An Empirical Analysis" IMF Staff papers, 38(1), $33-58,1991$

[21] T. U. Wai, C. H. Wong. Determinants of Private Investment in Developing Countries. Journal of Development Studies, 19 (1), 19-36, 1982.

[22] R. I. McKinnon. Money and Capital in Economic Development, Washington, DC: The Brookings Institute, 1973.

[23] E. S. Shaw. Financial Deepening in Economic Development, Oxford University Press, New York, 1973.

[24] R. S. Pindyck. Irreversibility, Uncertainty and Investment, Journal of Economic Literature, 1991.

[25] M. T. Hadjimichael, D. Ghura. Public Policies; Private Savings and Investment in Sub Sahara Africa: An Empirical Investigation, IMF Working Paper, WP/95/19, 1995.

[26] D. Ghura, T. J. Grennes. The Real Exchange Rate and Macroeconomic Performance in Sub-Sahara Africa: An Empirical Investment, IMF working paper, WP/95/19, 1993.

[27] A. Solimano. How Private Investment Reacts to Changing Macroeconomic Conditions". WPS, the World Bank No. 212,1989

[28] L. Serven, A. Solimano. Private Investment and Macroeconomic Adjustment: A Survey, World Bank Research Observer, 7(1), pp.95-114, 1992.

[29] E. Aryeetey. Private Investment under Uncertainty in Ghana, World Development, Vol. 22, No.8 pp 1211 - 1221, 1994.

[30] E.E. Ronge, P.K. Kimuyu. Private Investment in Kenya: Trends, Composition and Determinants, IPAR. Mimeograph, 1997.

[31] L. Ndikumana. Financial Determinants of Domestic Investment in Sub-Saharan Africa, World Development, Vol.
28, No.2, pp.381-400, 2000.

[32] K. Mlambo, T. W. Oshikoya. Macroeconomic factors and investment in Africa. Journal of African Economies, 10 (suppl 2), 12-47, 2001.

[33] A. Badawi. Private Capital Formation and Macroeconomic Policies in Sudan: Application of a simple Co-integrated Vector Autoregressive Model, Department of Economics, University of Khartoum, Sudan, 2005.

[34] O. A. Akanbi. Role of Governance in Explaining Domestic Investment in Nigeria. Working Paper Number 168. Department of Economics, University of Pretoria, South Africa, 2010.

[35] I. Fiestas, S. Sinha. Constraints to private investment in the poorest developing countries - A review of the literature, Nathan Association Ltd, UK, 2011.

[36] M. B. Ribeiro, R.T. Joanilio. An Econometric Analysis of Private-Sector Investment in Brazil, CEPAL Review 7:4, 2001.

[37] J. J. Heim. Does a Strong Dollar Increase Demand for both Domestic and Imported Goods, Journal of International Business and Economics, Vol. VII (3), 2007.

[38] J. J. Heim. What Determines Market Demand for investment Goods, Rensselaer Polytechnic Institute, Troy, New York, USA, 2008

[39] A. Chibber, D. Mansoor. Fiscal Policy and Private Investment in Developing Countries, Recherche Economique, XLIV, Numero 2-3, 1990.

[40] S. Johansen, K. Juselius. Maximum Likeliwood Estimation and Inference on Cointegration-With Application to the Demand for Money, Oxford Bulletin of Economics and Statistics: 52, 169-210, 1990.

[41] S. Khan, A. Khan. What determines Private Investment? The case of Pakistan, Pakistan Institute of Development Economics, Islamabad, WP 36, 2007.

[42] E. Seruvatu, T.K. Jayaraman. Determinant of Private Investment in Fiji, Economic Department, Reserve Bank of Fiji, Suva Fiji, Working paper 01/02, 2001.

[43] K. Froot, J. Stein. Exchange Rate and Foreign Direct Investment: An Imperfect Capital Market Approach", Quarterly Journal of Economics 106: 1197-217, 1991.

[44] R. S. Pindyck, A. Solimano. Economic Instability and Aggregate Investment, Policy Research Paper, the World Bank, 1993.

[45] A. B. Elhiraika. Foreign Capital Inflow, Domestic Credit and Private Investment in Swaziland, Department of Economics, CBE, United Arab Emirates University, 2001.

[46] M. Blejer, M.S. Khan. Government Policy and Private Investment in Developing Countries, IMF Staff Paper No. 131, pp 814-55, 1984.

[47] E. Ghani, M. Din. The Impact of Public Investment on Growth in Pakistan, Pakistan Development Review 45:1, 2006.

[48] www.financialdictionary.com; www.google.com 